\title{
Evaluación de la resistencia a los sulfatos de cemento con ceniza volante (utilizando el método de Koch \& Steinegger)
}

\author{
Sulfate resistance evaluation \\ of the cement with fly ash \\ (using the Koch \& Steinegger method)
}

IRASSAR, Edgardo F. ( $\left.{ }^{\star}\right)$; SOTA, Jorge D. $\left(^{\star \star}\right)$; BATIC, Oscar R. $\left(^{\star \star \star}\right)$ Laboratorio de Entrenamiento Multidisciplinario para la Investigación Tecnologica (LEMIT) Calle 52 entre 121 y 122. 1900 LA PLATA (ARGENTINA)

\section{SUMMARY}

The increase of active mineral admixtures consumption in contemporaneous cementiceous materials has stablished revision of some test methods. activas en los materiales cementiceos contemporáneos ha determinado la revisión de algunos métodos de ensayo utilizados para determinar sus propiedades.

En la evaluación de la durabilidad de los cementos compuestos, muchos ensayos de corta duración (de gran aplicación en cementos portland) dejan de tener validez, pues no permiten evaluar las mejoras que producen los materiales puzolánicos.

El método propuesto por KOCH \& STEINEGGER (1960) aparece como uno de los más apropiados para determinar el comportamiento de cementos con adiciones minerales activas frente al ataque de sulfatos.

En este trabajo se presentan los resultados alcanzados con ente ensayo en la determinación del comportamiento de un cemento portland normal (CPN) y uno resistente a los sulfatos (CPARS), adicionados con ceniza volante de bajo contenido en óxido de calcio. La ceniza se incorpora con tres finuras $\left(280,420\right.$ y $480 \mathrm{~m}^{2} / \mathrm{kg}$ - Blaine-). Estos resultado indican que esta adición mejora notablemente la resistencia a los sulfatos del CPN y en menor medida la del cemento ARS. La finura influye en la evolución de la resistencia mecánica en agua y en la resistencia química en las primeras edades.
In the evaluation of blended cement durability, many accelerated tests of large application in portland cements become unvalid, because they don't allow to value the improvements produced by pozzolan materials.

Koch-Steinegger Method appears as the most appropiate to evaluate sulfate resistance of cement with active mineral admixtures.

In this paper are presented the results obtained with this test in the evaluation of an ordinary portland cement (CPN) and one resisting sulfates (CPARS), with low calcium fly ash addition. Fly ash is incorporated with three fineness (280, 420 and $480 \mathrm{~m}^{2} / \mathrm{Kg}$ Blaine). The results show that this addition improve sulfate resistance of CPN and in minor way of ARS cement. Fly ash influences evolution of mechanical strength in water and chemical resistance at first ages.

\section{PALABRAS CLAVE:}

Resistencia a los sulfatos, ceniza volante, ensayos acelerado, mortero, durabilidad.

\section{INTRODUCCION}

La utilización de las adiciones minerales activas en la elaboración del hormigón ha sufrido un importante incremento en los últimos años debido a distintas necesidades requeridas en el mundo moderno. Entre ellas

\section{KEY WORDS:}

Sulfate resistance; fly ash; accelerated tests; mortar; durability.

\section{INTRODUCTION}

The use of active mineral admixtures in concrete elaboration has suffered an important increase in the last years, because of different necessities in modern wold. We can quot: decrease of energy consumption to develope

(*) Becario de Perfeccionamiento CONICET-LEMIT.

$(\star \star)$ Profesional CIC-LEMIT.

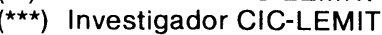


podemos citar: la disminución del consumo de energia para fabricar los materiales cementíceos, la eliminación de desechos industriales que contaminan el medio ambiente y la construcción de estructuras que requieren materiales con mejores característricas mecánicas, mayor durabilidad y menor costo.

Entre las adiciones minerales activas, la ceniza volante ocupa un papel destacado. Se la utiliza con distintos fines específicos: uno de ellos contrarrestar el ataque al hormigón del medio agresivo que contiene sulfatos. Varios autores [1, 2] coinciden en el incremento de la resistencia a los sulfatos que confieren las cenizas volantes al hormigón. Por otro lado, no todas las cenizas volantes poseen este efecto beneficioso: siempre ha de optarse por cenizas de bajo contenido de óxido de calcio (Clase F - ASTM C-618), sin descuidar la composición química del cemento a utilizar y la razón agua/cemento que gobierna la permeabilidad del hormigón. La mayor resistencia a los sulfatos que los cementos presentan, conteniendo ceniza volante, debe buscarse en tres causas principales: a) La disminución relativa del $\mathrm{C}_{3} \mathrm{~A}$ en el ligante compuesto. b) El taponamiento de los grandes capilares de la matriz cementícea por el producto de la reacción puzolánica. c) La disminución del $\mathrm{CH}$ presente en la pasta de cemento [9]. Estas acciones se ven afectadas por variables propias de la ceniza volante (finura, reactividad, composición mineralógica) y por causas exógenas a ella (composición del cemento, relación agua/cemento, curado, porcentaje de reemplazo). Esta gran variedad de causas debe analizarse con un método de ensayo apropiado y de relativa corta duración.

Los ensayos propuestos por Le ChatelierAnstett-Blondiau y la norma ASTM C-452 no permiten una correcta evaluación del ligante con ceniza volante [4]. Por tal razón se ha estudiado el método de ensayo propuesto por $K O C H$ \& STEINEGGER [5] que, según Calleja [6], aparece como uno de los más apropiados para tal determinación.

\section{ESTUDIO EXPERIMENTAL}

En este trabajo se estudia la influencia del reemplazo de parte de cemento portland normal o resistente a los sulfatos - tipo I y V respectivamente, según ASTM C-150- por ceniza volante de bajo contenido en óxido de calcio, frente al ataque de una disolución de sulfato de sodio. También se estudia la influencia de la finura de la adición. cementiceous materials; elimination of by-products which contaminate the atmposphere and the construction of structures which needed materials with better mechanical characteristics, more durability and less cost.

Among active mineral additions, fly ash is prominent. It is used with different specific purposes, one of them is to control sulfate attack to concrete.

Several authors $(1,2)$ agreed there is an increase in sulfate resistance produced by fly ashes in concrete. On the other hand, not all fly ashes have this beneficial effect, yuo must ever choose low calcium fly ashes (Class F; ASTM-C-618), without forgetting chemical composition of used cement and water/cement ratio.

The better sulfate resistance that present cements with fly ash must be attributed to three main reasons:

a) Relative decrease of $C_{3} A$ in bleded cement; b) Pore size refinement of large capilars of cementiceous matrix by pozzolanic reaction product; c) Decrease of $\mathrm{CH}$ in cement paste (3).

This actions are affected by variables of fly ash (fineness, reactivity, mineralogical composition) and extern reasons (cement composition, water/cement ratio, curing, percentage of replacement). This variable reasons must be analized with an appropiated test method and short duration.

Test propossed by Le Chatelier-AnstettBlondiau and ASTM-C-452 don't give a correct valoration of cement with fly ash (4). For this reason it was studied Koch-Steinegger Method (5), which according to Calleja (6) appears like one of the most appropiate for that determination.

\section{EXPERIMENTAL STUDY}

In this paper it is study the influence of replacement of part of ordinary or sulfate resistent portland cement - Type $\mathrm{I}$ and $\mathrm{V}$ respectivelly, according to ASTM-C-150- by low calcium fly ash, in front of sodium sulfate solution attack. It's also studied influence of fly ash fineness. 


\subsection{Materiales utilizados}

\subsubsection{Cemento}

Se han utilizado un cemento portland normal (CPN) conteniendo $7,7 \%$ de $\mathrm{C}_{3} \mathrm{~A}$ y un cemento portland resistente a los sulfatos (CPARS) con $0 \%$ de $\mathrm{C}_{3} \mathrm{~A}$. Sus características químicas y físicas se informan en la Tabla I.

\subsection{Used materials}

\subsubsection{Cement}

It was used ordinary portland cement (CPN) with $C_{3} A 7.7 \%$ and a portland sulfate resistent cement (CPARS) without $C_{3} A$. In table I are shown their physical and chemical characterisitics.

TABLA I (TABLE I)

Características químicas y físicas de los cementos y las cenizas volantes* (Physical and chemical characteristics of cements and fly ashes)

\begin{tabular}{|c|c|c|c|c|c|}
\hline Cemento/Adición (Cement/Fly ash) & CPN & CPARS & CV1 & CV2 & Cv3 \\
\hline \multicolumn{6}{|c|}{ Composición Química (\%) [Chemical composition (\%)] } \\
\hline Residuo (Ins) & 0,10 & 0,60 & & & \\
\hline $\mathrm{P} \times \mathrm{C}(L \times I)$ & 2,50 & 1,90 & 0,72 & 1,80 & 0,84 \\
\hline $\mathrm{SO}_{3}$ & 1,90 & 2,30 & 0,59 & 0,53 & 0,38 \\
\hline $\mathrm{MgO}$ & 1,10 & 1,00 & 2,06 & 2,06 & 3,06 \\
\hline $\mathrm{SiO}_{2}$ & 21,10 & 21,60 & 59,60 & 58,80 & 60,40 \\
\hline $\mathrm{Fe}_{2} \mathrm{O}_{3}$ & 4,20 & 6,90 & 6,90 & 6,70 & 7,60 \\
\hline $\mathrm{Al}_{2} \mathrm{O}_{3}$ & 5,60 & 3,30 & 24,00 & 24,60 & 23,50 \\
\hline $\mathrm{CaO}$ & 61,40 & 61,40 & 4,90 & 3,50 & 2,70 \\
\hline $\mathrm{Na}_{2} \mathrm{O}$ & 0,84 & 0,02 & 0,84 & 1,87 & 1,13 \\
\hline $\mathrm{K}_{2} \mathrm{O}$ & 0,58 & 0,90 & 0,31 & 0,41 & 0,39 \\
\hline Alcalis Tot. $\left(\right.$ en $\left.\mathrm{Na}_{2} \mathrm{O}\right)$ & 1,22 & 0,61 & & & \\
\hline $\mathrm{SiO}_{2}+\mathrm{Al}_{2} \mathrm{O}_{3}+\mathrm{Fe}_{2} \mathrm{O}_{3}$ & & & 90,50 & 90,10 & 91,50 \\
\hline \multicolumn{6}{|c|}{ Composición potencial (\%) [Potential composition (\%)] } \\
\hline $\mathrm{C}_{3} \mathrm{~S}$ & 37,20 & 44,20 & & & \\
\hline $\mathrm{C}_{2} \mathrm{~S}$ & 32,60 & 28,20 & & & \\
\hline $\mathrm{C}_{3} \mathrm{~A}$ & 7,70 & 0,00 & & & \\
\hline $\mathrm{C}_{4} \mathrm{AF}$ & 12,80 & & & & \\
\hline$\left(\mathrm{C}_{2} \mathrm{~F}+\mathrm{C}_{4} \mathrm{AF}\right) \mathrm{ss}$ & & 21,00 & & & \\
\hline \multicolumn{6}{|l|}{ Características físicas (Physical characteristics) } \\
\hline \multicolumn{6}{|l|}{ Superficie Especifica (Specific surface) } \\
\hline (Blaine) $\left(\mathrm{m}^{2} / \mathrm{kg}\right)$ & 342 & 408 & 286 & 420 & 480 \\
\hline \multicolumn{6}{|l|}{ Peso específico (Specific gravity) } \\
\hline$\left(\mathrm{g} / \mathrm{cm}^{3}\right)$ & 3,14 & 3,16 & 1,92 & 2,20 & 2,31 \\
\hline \multicolumn{6}{|l|}{ Actividad Puzolánica con cemento } \\
\hline (Pozzolanic index with cement) & & & $76 \%$ & $103 \%$ & $105 \%$ \\
\hline \multicolumn{6}{|c|}{ Resistencia mecánica (MPa) [Mechanical strength (MPa)] } \\
\hline \multicolumn{6}{|l|}{ Flexión (Flexural strength) } \\
\hline 7 días (days) & 7,40 & 7,30 & & & \\
\hline 28 dias (days) & 8,70 & 8,40 & & & \\
\hline \multicolumn{6}{|l|}{ Compresión (Compressive strength) } \\
\hline 7 días (days) & 36,00 & 34,40 & & & \\
\hline 28 dias (days) & 49,00 & 48,00 & & & \\
\hline
\end{tabular}

* Determinadas según normas IRAM y ASTM C-311. (Determinad according IRAM Standart and ASTM C-311).

\subsubsection{Ceniza volante}

Se han utilizado tres cenizas volantes provenientes de una central termoeléctrica de
2.1.2. Fly ash

There were used three fly ashes from a thermoelectric central of Argentine, in which a 
la República Argentina, en la cual el combustible es carbón sub-bituminoso tipo A (ASTM D-388). La ceniza volante CV1 se usó como se recoge de los filtros ubicados antes de la chimenea de la central, mientras que las cenizas CV2 y CV3 - del mismo origen- han sido seleccionadas por medio de un separador neumático de partículas. Sus características físicas y composición química se encuentran detalladas en la Tabla I. Del análisis por DRX surge que los principales compuestos cristalinos de estas cenizas son $\alpha$-cuarzo y mullita; también se han detectado muscovita, sillima-nita, hematita, corindon, ortoclasa y ferrita magnésica en pequeñas proporciones. La figura 1 muestra el difractograma correspondiente a la CV1. subbituminous coal Type A (ASTM-D-388) is the fuel.

The CV1 fly ash was used like is pick up from filters placed before the chemin of the Central, while CV2 and CV3 ashes -of same originhave been selected by a neumatic selector of particles. In table I are detailed their physical characteristics and chemical composition. XRD analyses show that main cristaline compounds of these ashes are $\alpha$-quartz and mullite; they have also been detected muscovite, sillimanite, hematite, corindon, ortoclase and magnesic ferrite in few proportions. SRD pattern of CV1 is shown in figure 1.

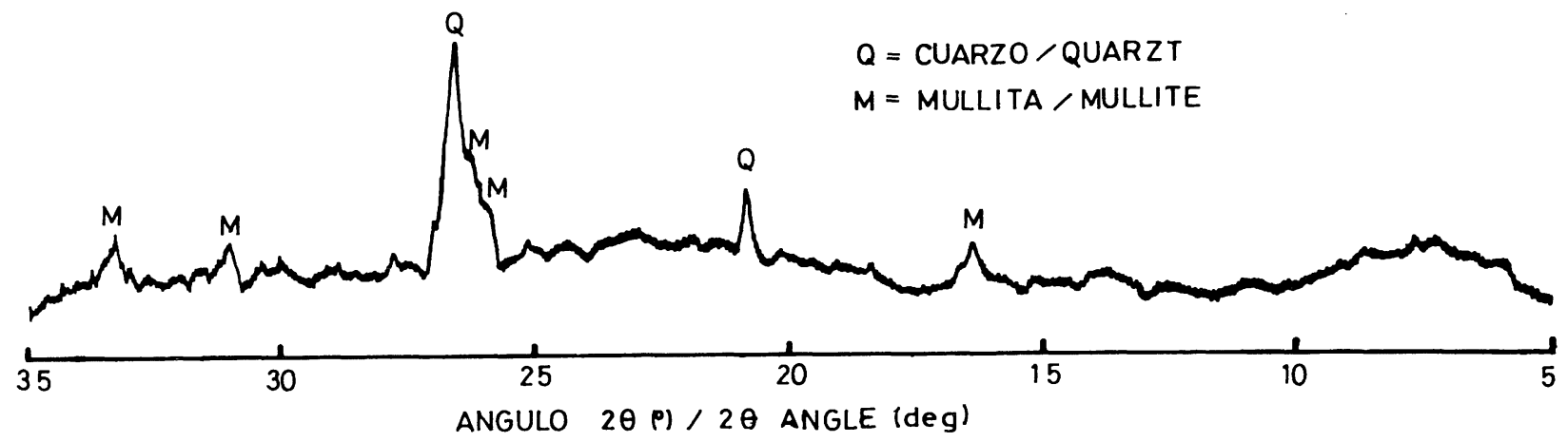

Fig. 1.-Diagrama obtenido por DRX de la ceniza volante CV1.

Fig. 1.-DRX. pattern of CV1 fly ash.

\subsubsection{Agregado fino}

Se empleó un agregado fino compuesto por dos partes de la fracción I y una de la fracción II. Cada fracción tiene la siguiente granulometría:

\subsubsection{Fine Aggregate}

It was used a fine aggregate composed by two parts of fraction I and one of fraction II. (See table).

$$
\begin{aligned}
& \text { Fracción I (Fraction I): } \\
& 100 \% 1 \mathrm{~mm}-590 \mu \mathrm{m} \text { (N. 18-35) } \\
& \text { Fracción II (Fraction II): } \\
& 7 \% 590 \mu \mathrm{m}-210 \mu \mathrm{m}(\mathrm{N} . \quad 35-70) \\
& 43 \% 210 \mu \mathrm{m}-88 \mu \mathrm{m}(\mathrm{N} .70-170) \\
& 50 \% 88 \mu \mathrm{m}-53 \mu \mathrm{m}(\mathrm{N} .170-230)
\end{aligned}
$$

La fracción I está compuesta por arena silícea natural y la fracción restante por cuarzo molido.

\subsection{Tecnica de ensayo}

Se confeccionó por cada edad de ensayo y
Fraction I is composed by natural siliceous sand and the rest fracction by ground quartz.

\subsection{Test technic}

For each test age studied solution (water and 
disolución en estudio (agua y sulfato de sodio) una serie de doce probetas de $10 \times 10 \times 60$ $\mathrm{mm}$, mortero 1:3 y razón agua/cemento $=0,6$. Una vez curadas durante 24 horas en cámara húmeda $\left(21^{\circ} \mathrm{C}\right.$ y $\left.\mathrm{HR}>90 \%\right)$ se las suspende en agua desmineralizada durante 21 días. A esta edad las series correspondientes se sumergen en una solución que contiene $10 \%$ en peso de $\mathrm{Na}_{2} \mathrm{SO}_{4} .10 \mathrm{H}_{2} \mathrm{O}\left(4.4 \% \mathrm{Na}_{2} \mathrm{SO}_{4}\right)$. Transcurridos $21+14,21+28,21+56$, $21+160$ y $21+340$ días se ensaya a flexión una serie curada en agua y otra en la solución agresiva. Analizados estadísticamente los valores obtenidos se calcula el coeficiente de corrosión (R) con la siguiente expresión: sodium sulfate solution) it was done a series of twelve specimens of $10 \times 10 \times 60 \mathrm{~mm} ; 1: 3$ mortar and water/cement ratio $=0.6$. After cured during 24 hours in moist cabinet $\left(21^{\circ} \mathrm{C}\right.$ and $\mathrm{RH}$ more than $90 \%)$, they are suspended in dismerilized water during 21 days. At this age, the corresponding series, are immege in a solution with $10 \%$ in weight of $\mathrm{Na}_{2} \mathrm{SO}_{4} \cdot 10$ $\mathrm{H}_{2} \mathrm{O}\left(4.4 \% \mathrm{Na}_{2} \mathrm{SO}_{4}\right)$. After $21+14 ; 21+28$; $21+56,21+160$ and $21+340$ days there were flexural tested series cured in water and other cured in agressive solution. The obtained values are stadisticaly analyzed, it is calculated corrosion coeficient $R$ as:

$$
\begin{aligned}
& \mathrm{R}=\frac{\text { Resistencia a flexión de la serie curada en disolución } \mathrm{Na}_{2} \mathrm{SO}_{4}}{\text { Resistencia a flexión de la serie curada en agua }} \\
& \mathrm{R}=\frac{\text { Flexural strength of cured serie in sodium sulfate solution }}{\text { Flexural strength of cured serie in water }}
\end{aligned}
$$

Este coeficiente permite evaluar la resistencia química. El valor de 0,7 (a la edad de $21+56$ días) es el límite propuesto por sus autores para definir la resistencia o no del ligante a los sulfatos. En este trabajo también se ha calificado el estado de las probetas mediante la escala visual de 6 a 1 como se puede apreciar en la figura 2. El valor que se informa corresponde al aspecto general de la serie.
This coeficient permits to evaluate chemical resistance. The propposed limit at $21+56$ days is 0.7 to define a sulfate resistent cement. In this paper was also classificated specimens condition by visual scale form 6 to 1 , shown in figure 2. The informed values corresponds to the general aspect of the series.

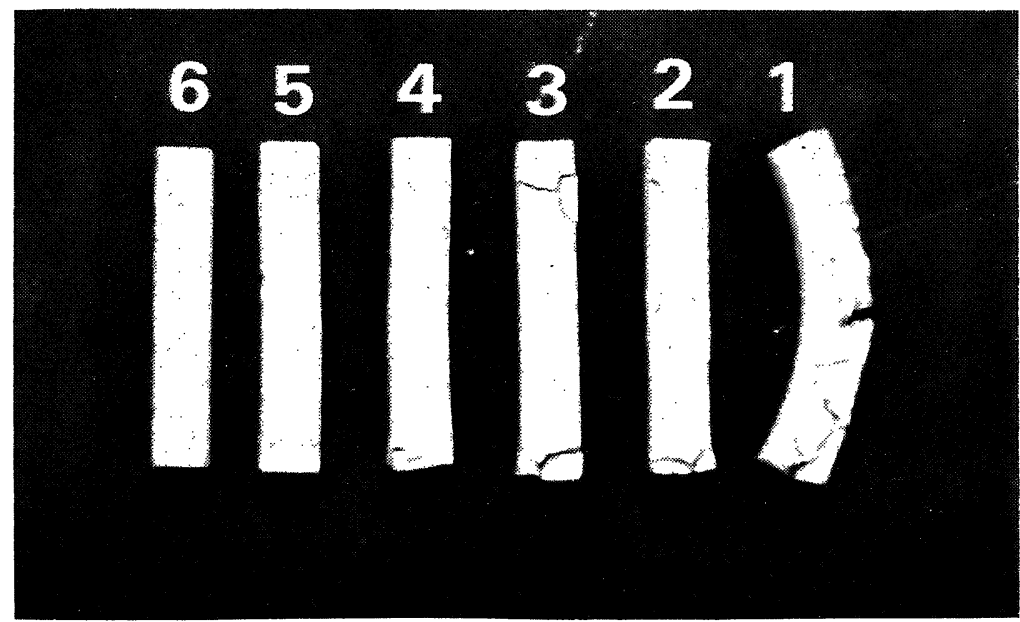

Fig. 2.- La fotografía muestra la escala visual de la utilizada para evaluar el aspecto de las probetas sumergidas en la disposición de $\mathrm{Na}_{2} \mathrm{SO}_{4}$

Fig. 2. - The photograph show visual scale used to evaluate specimens aspect of prisms immerse in $\mathrm{Na}_{2} \mathrm{SO}_{4}$ solution.

6. No presenta fisuras. (Non cracks).

5. Presenta pequeñas fisuras en los extremos y en las aristas vivas. (Ligth cracks in the extremes and corners of prism).

4. Presenta fisuras en los extremos y en los bordes. (Cracks in the extremes and corners of prism).

3. Totalmente fisurados los extremos y comienzan a evidenciarse fisuras en su cuerpo. (Prism extremestotaly cracked and cracks in the center).

2. Totalmente fisurada y con un leve curvatura. No es posible ensayarla. (Prisms totaly cracked and ligth curvature. No tested).

1. Totalmente fisurada, muy curvada y a veces separada en dos tramos. No es posible ensayarla. (Prisms totaly cracked, greather curvature and in same case broken. No tested). 
Los valores de resistencia a la flexión informados corresponden al valor medio de los doce ensayos, donde se eliminaron aquellos cuyo desvío superaba el $10 \%$ del promedio.

Las mezclas estudiadas corresponden a reemplazos del 0,20 y $30 \%$ de cemento por ceniza volante, en peso.

\section{RESULTADOS Y DISCUSION}

\subsection{Cemento ARS (Tipo V)}

Los resultados obtenidos utilizando este cemento se muestran en la Tabla II y las figuras 3,4 y 5 .
The informed values of flexural strength correspond to the mean value to the twelve tests; where there were eliminated those bars which deferal from the average more than $10 \%$.

The studied mixes corresponds to replacements in weight of 0; 20 and $30 \%$ of cement by fly ash.

\section{RESULT AND DISCUSSION}

\subsection{ARS cement (type V)}

Obtained results using this cement are shown in table II and figures 3, 4 and 5.

TABLA II (TABLE II)

Resistencia a flexión en mPA, coeficiente de corrosión (R) y aspecto visual (AV) de los morteros confeccionados con cemento ARS.

(Flexural strength in $m P A$, corrosion coefficient $(R)$ and visual raiting (AV) of mortars made with ARS cement

\begin{tabular}{|c|c|c|c|c|c|c|c|}
\hline \multirow{2}{*}{\multicolumn{2}{|c|}{ Cemento (Cement) }} & \multicolumn{3}{|c|}{ Edad (días) [Age (days)] } & \multirow{3}{*}{$\begin{array}{r}21+56 \\
8,02\end{array}$} & \multirow{3}{*}{$\frac{21+160}{7,41}$} & \multirow{3}{*}{$\frac{21+340}{7,63}$} \\
\hline & & 21 & $21+14$ & $21+28$ & & & \\
\hline & $H^{\star}$ & 6,69 & 6,96 & 7,86 & & & \\
\hline \multirow[t]{4}{*}{ ARS } & SN & & 7,63 & 7,92 & 7,38 & 5,86 & 5,62 \\
\hline & $\mathrm{R}$ & & 1,10 & 1,01 & 0,92 & 0,79 & 0,74 \\
\hline & $\mathrm{AV}$ & & 6 & 6 & 6 & 5 & 5 \\
\hline & $\mathrm{H}$ & 4,59 & 4,85 & 5,77 & 6,20 & 6,51 & 6,45 \\
\hline \multirow[t]{4}{*}{$+20 \% \mathrm{CV} 1$} & $\mathrm{SN}$ & & 6,12 & 6,53 & 7,26 & 4,39 & 4,49 \\
\hline & $\mathrm{R}$ & & 1,26 & 1,13 & 1,17 & 0,67 & 0,69 \\
\hline & AV & & 6 & 6 & 6 & 4 & 3 \\
\hline & $\mathrm{H}$ & 3,68 & 4,20 & 4,64 & 5,33 & 6,54 & 6,36 \\
\hline \multirow[t]{4}{*}{$+30 \% \mathrm{CV}_{1}$} & $\mathrm{SN}$ & & 5,58 & 6,36 & 6,90 & 4,83 & 3,33 \\
\hline & $\mathrm{R}$ & & 1,33 & 1,37 & 1,29 & 0,74 & 0,52 \\
\hline & AV & & 6 & 6 & 6 & 5 & 3 \\
\hline & $\mathrm{H}$ & 6,23 & 6,74 & 7,19 & 7,35 & 8,22 & 8,62 \\
\hline \multirow[t]{4}{*}{$+20 \% \mathrm{CV} 3$} & SN & & 7,37 & 9,30 & 8,60 & 4,86 & 3,76 \\
\hline & $\mathrm{R}$ & & 1,09 & 1,29 & 1,17 & 0,59 & 0,44 \\
\hline & $\mathrm{AV}$ & & 6 & 6 & 5 & 5 & 4 \\
\hline & $\mathrm{H}$ & 5,80 & 6,38 & 7,10 & 7,50 & 7,78 & 8,61 \\
\hline \multirow[t]{3}{*}{$+30 \%$ CV3 } & SN & & 7,78 & 8,11 & 8,97 & 5,60 & 4,41 \\
\hline & $\mathrm{R}$ & & 1,22 & 1,14 & 1,19 & 0,72 & 0,51 \\
\hline & AV & & 6 & 6 & 6 & 5 & 4 \\
\hline
\end{tabular}

* $\mathrm{H}=$ agua (water). $\mathrm{SN}=$ disolución de sulfato de sodio (sodium sulfate solution).

Del análisis de los resultados se observa que las mezclas con $\mathrm{CV} 3$ alcanzan la resistencia a flexión del cemento patrón, curado en agua, en el período de 77 a 180 días; en cambio los morteros con CV1 no la iguala al cabo de la duración del ensayo. Este comportamiento se debe a la mayor reactividad de la ceniza volante seleccionada. Cabe destacar que el cemento ARS, durante el curado previo (21 días), ha desarrollado el $85 \%$ de su
From the analysis of result it is observed that mixes with CV3 achieve the flexural strength of control cement, cured in water, in the period of 7 to 180 days, but mortars with CV1 during the test do not equal it. ARS cement during previous curing (21 days) has developed $85 \%$ of its final strength, mixes with $20 \%$ of replacement, $70 \%$, and with $30 \%$ of replacement, more than $60 \%$. The differences with control strength at 21 days are $22 \%, 45$ 
resistencia final; las mezclas con $20 \%$ de reemplazo el $70 \%$, y las de $30 \%$ de reemplazo algo más del $60 \%$. Las diferencias que existen con la resistencia del patrón, a los 21 días, son de $22 \%, 45 \%, 7 \%, 13 \%$ para las mezclas que contienen $20 \%$ CV1, 30 \% CV1, $20 \%$ CV3 y $30 \%$ CV3 respectivamente.

La resistencia a flexión de los prismas confeccionados con cemento ARS y curados en la disolución con sulfato de sodio experimentan un ligero incremento -con respecto al curado en agua- durante los $21+$ 28 días. Posteriormente decae lentamente hasta finalizar el ensayo. En cambio, en todas las mezclas con ceniza volante se presenta un incremento en la resistencia de importancia hasta los 21 + 56 días, y luego cae bruscamente.

El comportamiento descrito en el párrafo anterior tiene su explicación en los procesos físico-químicos que ocurren en el mortero. Al entrar en contacto el mortero con la solución agresiva, los iones sulfato se difunden en su
$\%, 7 \%, 13 \%$ for mixes with $20 \%$ CV1, $30 \%$ CV1, 20 \% CV3, 30 \% CV3, respectively.

Flexural strength of prisms made with ARS cement and cured in sulfate solution have a lightly increase - respect ot water curedduring $21+28$ days.

Then, it decreases slowly until the end of the test. But, all cements with fly ash have an important increase of strength until $21+56$ days, and then it dropps abruptly.

The above described behaviour is based in physical-chemical processes that occured in the mortar. When mortar is in contact with the aggresive solution, sulfate ions difund in its mass. There are reactions with labil

足

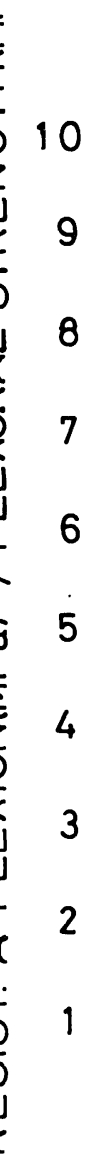

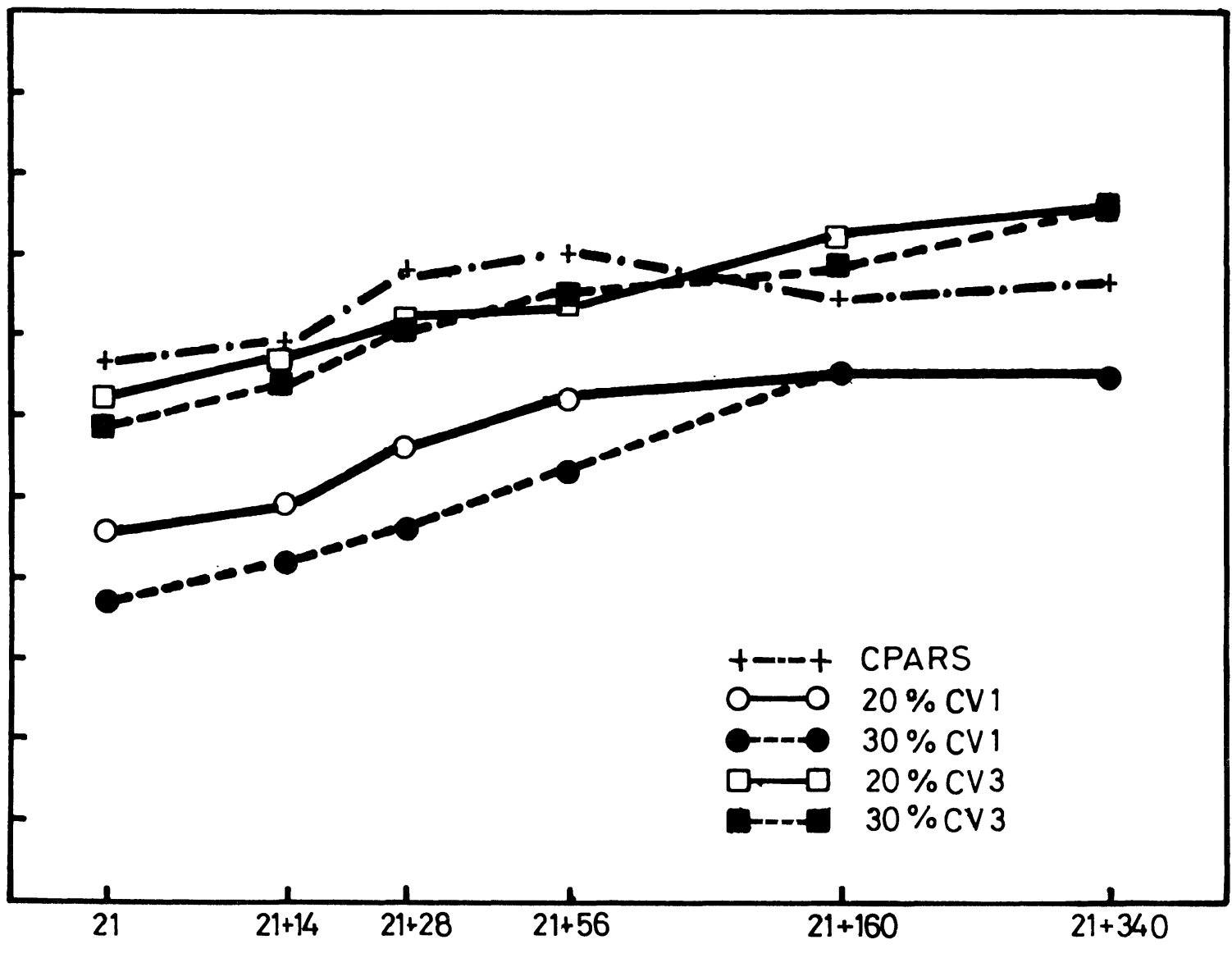

EDAD (DIAS) / AGE (DAYS)

Fig. 3.-Variación de la resistencia a flexión de los prismas confeccionados con cemento ARS y estacionados en agua.

Fig. 3.-Flexural strength variation of prisms made with ARS cement and stored in water. 
masa. Alli reaccionan con los compuestos lábiles del cemento $\left(\mathrm{CH}, \mathrm{C}_{3} \mathrm{ASH}_{12}, \mathrm{C}_{3} \mathrm{AH}_{6}\right)$ generando compuestos que se depositan preferentemente en los poros. Este taponamiento de poros ocasiona el incremento de la resistencia en las primeras edades. Nuevos aportes de iones sulfato provoca el crecimiento de los cristales de yeso, ettringita o ambos, que originan la microfisuración de la probeta y la consecuente caída de la resistencia. En la opinión de los autores, a mayores incrementos de la resistencia en las primeras edades de exposición, prosigue una mayor caída de la misma. El mayor incremento de la resistencia en las mezclas con ceniza puede deberse a una mayor porosidad de las probetas a la fecha del "debut" del ataque, ya que el grado de hidratación del ligante es menor. Por esta razón sería conveniente estudiar la influencia del tiempo de curado previo en el caso de estudiar cementos compuestos. components of cement $\left(\mathrm{CH}, \mathrm{C}_{3} \mathrm{ASH}_{12}, \mathrm{C}_{3} A \mathrm{H}_{6}\right.$ ) producing compounds which deposits in pores, preferently. This pores filling produced the strength increase in first ages. New additions of sulfate ions provoque the growth of gypsum cristals, ettringite, or both, which produced specimen crack and the consequent decrease of strength. In author's opinion, after greater increases of strength in first ages of exposition, continues a greater decrease of it. The greater increase of mixes strength with fly ash can be due to the greater porosity of the specimens at the attack start, because the degree of hydratation of the cemet is less. For this reason it would be convenient to study the influence of previous curing time when studying blended cements.

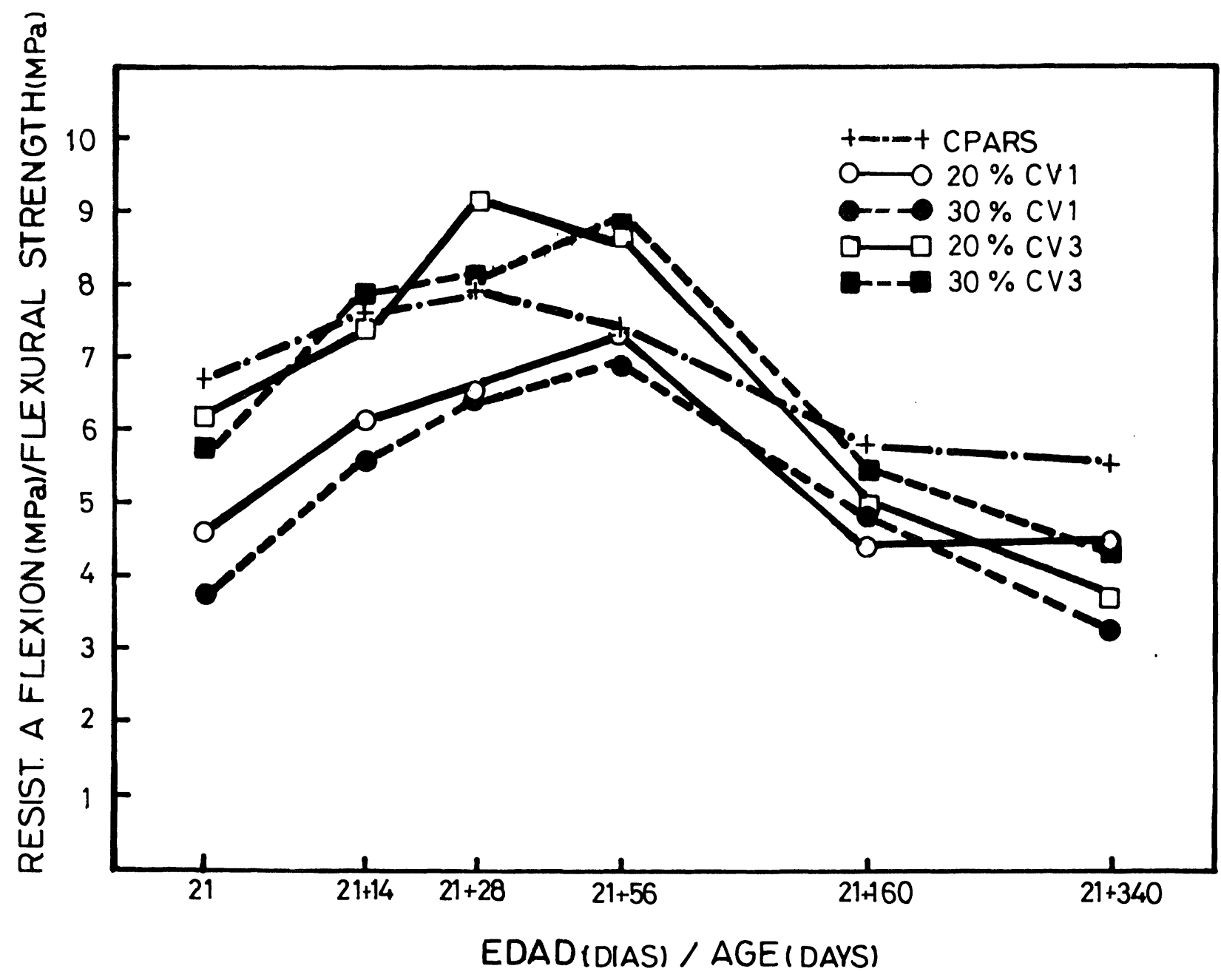

Fig. 4.-Variación de la resistencia a flexión de los prismas confeccionados con cemento ARS y estacionados en la disolución de sulfato de sodio.

Fig. 4.-Flexural strength variation of prisms made with ARS cement and stored in sodium sulfate solution. 


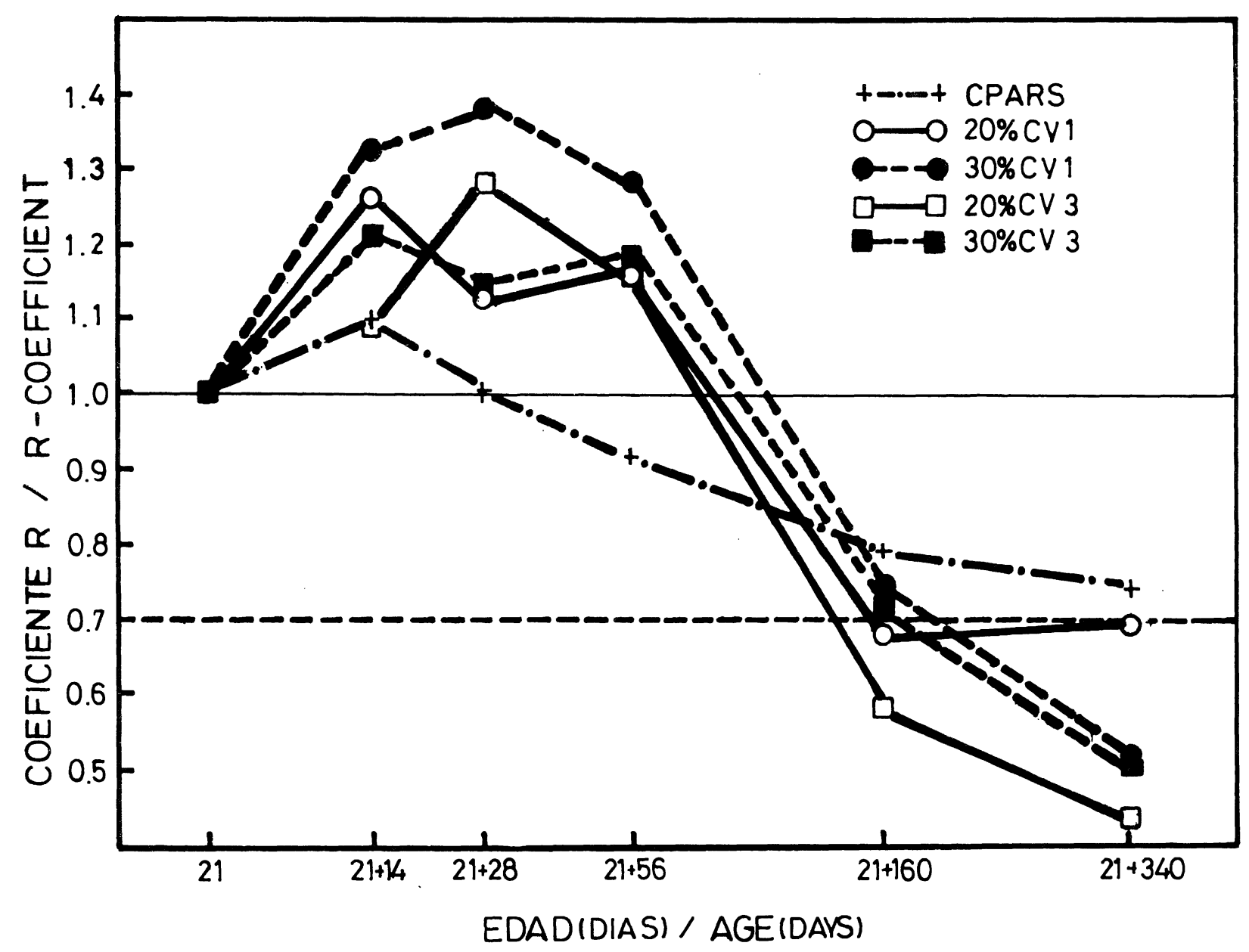

Fig. 5.-Variación del Coeficiente de corrosión R en las mezclas confeccionadas con cemento ARS.

Fig. 5.-R-Corrosion coefficient variation in mortars made with ARS cement.

La resistencia química de todas las mezclas es elevada. El coeficiente de corrosión $\mathrm{R}$ a los $21+56$ días supera con holgura el límite propuesto. Para el cemento sin adición, $R$ es mayor al límite hasta finalizar el ensayo. Para las mezclas con ceniza volante el resultado final es menor a 0,7 y no se aprecian diferencias importantes entre las dos cenizas, consecuencia de la corrosión ácida del mortero (formación de yeso).

\subsection{Cemento normal (Tipo I)}

Los resultados alcanzados en los morteros, que contienen este cemento, se informa en la tabla III y figuras 6,7 y 8 .

Los prismas confeccionados con cementos portland normal y ceniza volante, curados en agua, presentan una evolución de la resistencia más rapida que la correspondiente mezcla con cemento ARS. En nuestra opinión esto se debe a la distinta composición química de los cementos portland, en especial el mayor contenido de álcalis del CPN que
Chemical resistance of all mixes is high. Corrosion coeficient $R$, at $21+56$ days exceeds the proposed limit. $R$ is greater than limit until finishing test, for cement without addition. For mixes with fly ash, final result is smaller to 0.7 and there are no important differences between both ashes, as consequece of acidic corrosion of mortar -gypsum formation-.

\subsection{Ordinary portland cement (type I)}

In table III and figures 6, 7 and 8 are shown the results of mortars with cemets.

Prisms elaborated with ordinary portland cement and fly ash, cured in water, present a strength evolution faster than mix wih ARS cement. In our opinion this is due to the different chemical composition of portland cements, specially the greater content of alcalis of CPN, which improve fly ash reaction. Mortars with the other fly ash reach this 
favorece la reacción de la ceniza volante. Los morteros con CPN y cenizas CV2 y CV3

alcanzan la resistencia del patrón en el período comprendido ente los 49 y 77 días. El mortero con la ceniza restante alcanza esta resistencia al cabo del año, debido a su menor reactividad.

La resistencia a flexión a los 21 días, para un reemplazo del $20 \%$, oscila entre el 80 y $88 \%$ de la correspondiente al patrón; y entre el 57 y $75 \%$ para un reemplazo del $30 \%$.

En cuanto a la resistencia a flexión de las series curadas en la disolución de sulfato de sodio, se observa un importante incremento de la misma hasta los $21+28$ días para los dos porcentajes de adición y las tres finuras de la ceniza. Luego se inicia la disminución de la resistencia, debida a la fisuración originada strength at one year, due to its less reactivity.

Flexural strength at 21 days for a replacement of $20 \%$ oscillates between 80 and $88 \%$ of the corresponding control; and between 57 and $75 \%$ for a replacement of $30 \%$.

Considering flexural strengths of the series cured in a sodium sulfate solution, it is observed an important increase until $21+28$ days for both addition percentages and the three fineness. Then flexural strength decreases, due to the fissuration due to development of expansive compounds in first

TABLA III (TABLE III)

Resistencia a flexión en $\mathrm{mPa}$, coeficiente de corrosión (R) y aspecto visual (AV) de las probetas confeccionadas con cemento portland normal

(Flexural strength in $M P A$, corrosion coefficient $(R)$ and visual aspect (AV) of mortars made with CPN cement

\begin{tabular}{|c|c|c|c|c|c|c|c|}
\hline \multirow{2}{*}{\multicolumn{2}{|c|}{ Cemento (Cement) }} & \multicolumn{4}{|c|}{ Edad (Dias) [Age (Days)] } & \multirow[b]{2}{*}{$21+160$} & \multirow[b]{2}{*}{$21+34 C$} \\
\hline & & 21 & $21+14$ & $21+28$ & $21+56$ & & \\
\hline & $\mathrm{H}^{\star}$ & 7,18 & 7,10 & 7,13 & 7,21 & 8,06 & 7,59 \\
\hline \multirow[t]{4}{*}{ CPN } & SN & & 6,67 & 5,28 & 3,04 & 1,21 & n.d. ${ }^{\star \star}$ \\
\hline & $\mathrm{R}$ & & 0,94 & 0,74 & 0,42 & 0,16 & n.d. \\
\hline & AV & & 5 & 4 & 3 & 2 & 2 \\
\hline & $\mathrm{H}$ & 5,68 & 5,73 & 6,07 & 6,45 & 7,54 & 7,52 \\
\hline \multirow[t]{4}{*}{$+20 \% \mathrm{CV}_{1}$} & SN & & 6,13 & 6,04 & 5,37 & 2,49 & n.d. \\
\hline & $\mathrm{R}$ & & 1,07 & 1,00 & 0,83 & 0,33 & n.d. \\
\hline & AV & & 6 & 5 & 3 & 2 & 1 \\
\hline & $\mathrm{H}$ & 4,09 & 4,66 & 4,87 & 5,08 & 6,45 & 7,03 \\
\hline \multirow[t]{4}{*}{$+30 \% \mathrm{CV}_{1}$} & SN & & 6,01 & 6,24 & 5,28 & 2,41 & n.d. \\
\hline & $R$ & & 1,29 & 1,28 & 1,04 & 0,35 & n.d. \\
\hline & AV & & 6 & 5 & 4 & 3 & 2 \\
\hline & $\mathrm{H}$ & 6,23 & 6,27 & 7,23 & 8,24 & 8,94 & 9,15 \\
\hline \multirow[t]{4}{*}{$+20 \%$ CV2 } & SN & & 7,55 & 7,12 & 6,10 & 2,78 & n.d. \\
\hline & $R$ & & 1,20 & 0,98 & 0,74 & 0,31 & n.d. \\
\hline & AV & & 6 & 4 & 3 & 2 & 1 \\
\hline & $\mathrm{H}$ & 5,21 & 6,71 & 7,18 & 8,19 & 8,56 & 9,44 \\
\hline \multirow[t]{4}{*}{$+30 \%$ CV2 } & SN & & 7,62 & 8,34 & 7,70 & 4,40 & n.d. \\
\hline & $\mathrm{R}$ & & 1,14 & 1,16 & 0,94 & 0,51 & n.d. \\
\hline & $A V$ & & 6 & 6 & 5 & 3 & 2 \\
\hline & $\mathrm{H}$ & 6,30 & 6,40 & 6,44 & 7,81 & 8,61 & 10,46 \\
\hline \multirow[t]{4}{*}{$+20 \%$ CV3 } & SN & & 7,96 & 7,92 & 6,47 & 2,58 & n.d. \\
\hline & $\mathrm{R}$ & & 1,24 & 1,23 & 0,83 & 0,30 & n.d. \\
\hline & $A V$ & & 6 & 6 & 5 & 3 & 1 \\
\hline & $H$ & 4,90 & 5,69 & 6,68 & 6,96 & 7,30 & 8,84 \\
\hline \multirow[t]{3}{*}{$+30 \%$ CV3 } & SN & & 6,89 & 8,18 & 8,32 & 3,47 & n.d. \\
\hline & $\mathrm{R}$ & & 1,21 & 1,22 & 1,20 & 0,48 & n.d. \\
\hline & AV & & 6 & 6 & 5 & 4 & 1 \\
\hline
\end{tabular}

* $\mathrm{H}=$ agua (water). $\mathrm{SN}=$ disolución de sulfato de sodio (sodium sulfate solution). 
por la formación de compuestos expansivos en las primeras edades. Esta caída es más marcada cuando se reemplaza el $20 \%$ de cemento. En el cemento portland sin adición no se alcanza a registrar el incremento de la resistencia.

La variación del coeficiente $R$ muestra un mejor comportamiento químico de las mezclas que contienen cenizas volantes. Todas ellas superan el valor límite a los $21+56$ días. Se comprueba un mayor aumento de la resistencia a los sulfatos en las mezclas que contienen un reemplazo del $30 \%$ de cemento.

La incidencia de la finura sólo se manifiesta en las primeras edades para el $20 \%$ de reemplazo y no existe una tendencia marcada para el $30 \%$ de reemplazo. Al cabo de 21 + 160 días todas las mezclas arriban a un valor de $\mathrm{R}$ similar. La figura 9 muestra la variación del coeficiente $R$ a cada edad con la finura de la adición. ages. This decrease is more evident when it is replace $20 \%$ of cement. In portland cement without addition it cannot be record the increase of strength.

$R$-Coeficient variation shows a better chemical behaviour of mixes with fly ashes. All of them supere limit value at $21+56$ days. There is a greater increase of sulfate resistance in mixes with $30 \%$ cement replacement.

The fineness incidence only is observed in first ages for $20 \%$ of replacement and there isn't evident incidence for $30 \%$ of replacement. At $21+160$ days all mixes arrive to a similar $R$ $R$-Coeficient variation at each age with addition fineness are shows in figure 9.

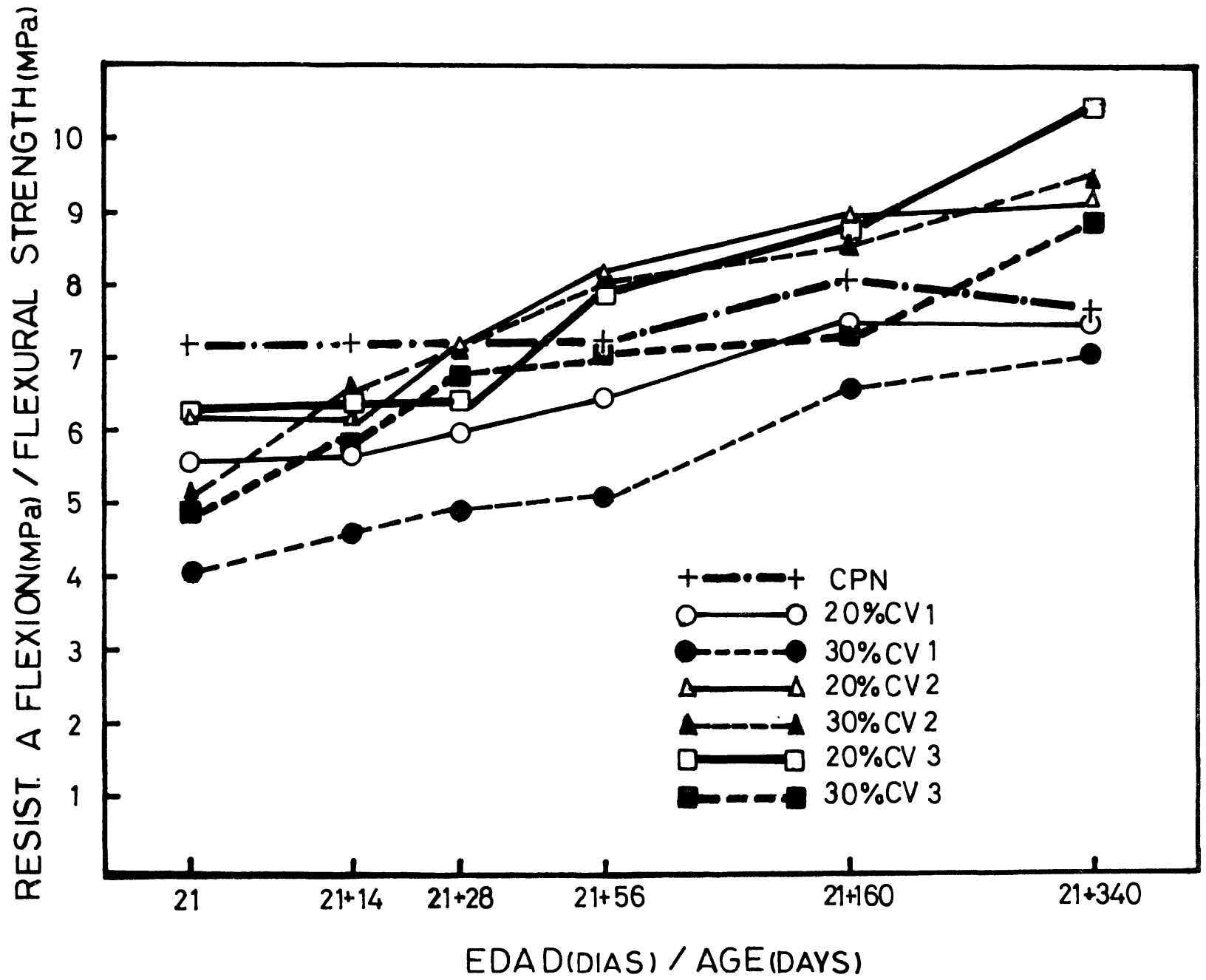

Fig. 6.-Variación de la resistencia a flexión de los prismas confeccionados con cemento CPN y estacionados en agua.

Fig. 6.-Flexural strength variation of prisms made with CPN cement and stored in water. 


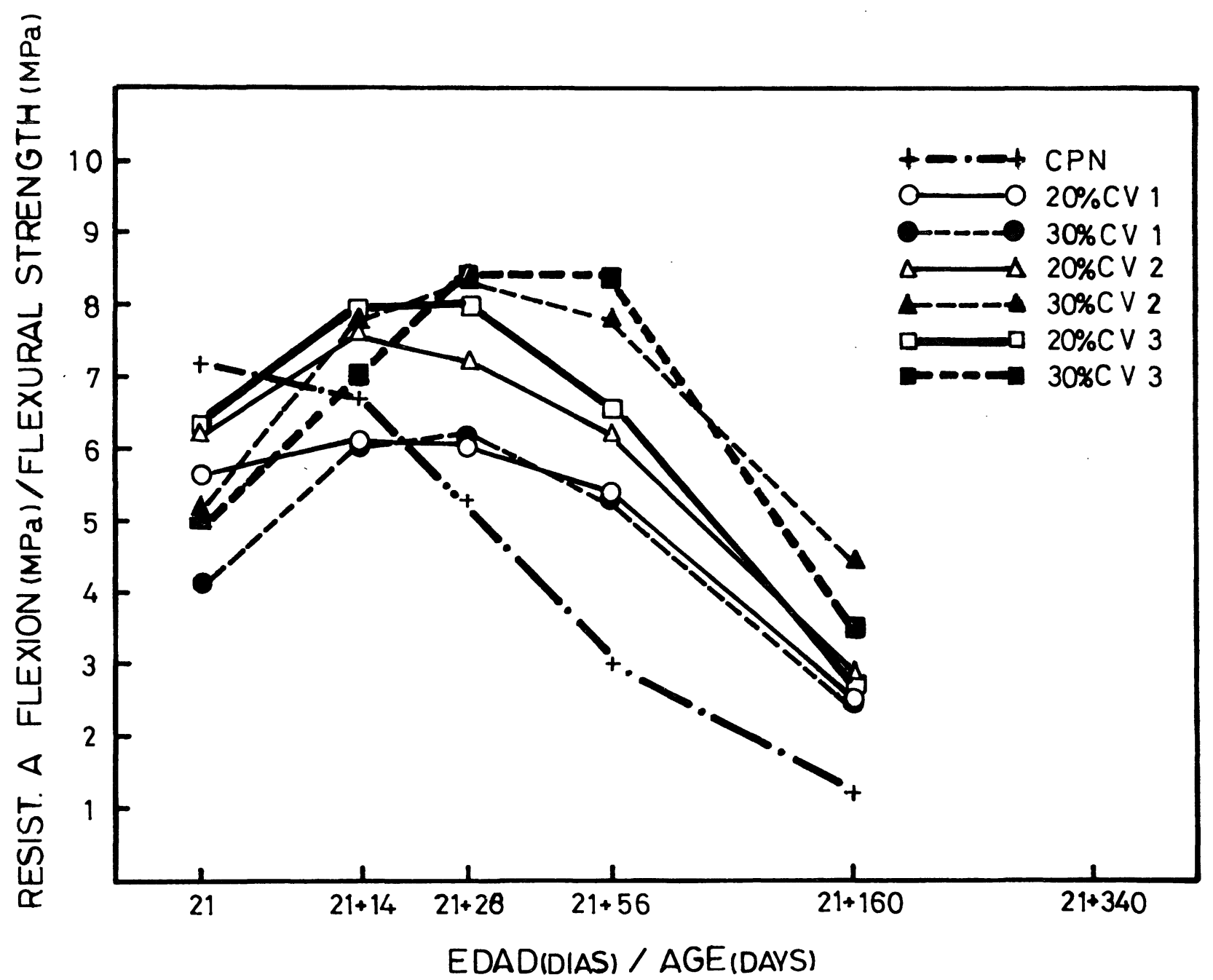

Fig. 7.- Variación de la resistencia a flexión de los prismas confeccionados con cemento CPN y estacionados en la disolución de sulfato de sodio.

Fig. 7.-Flexural strength variation of prisms made with CPN cement and stored in sodium sulfate solution.

En la figura 10 se puede ver el estado final de los prismas al cabo de $21+340$ días de exposición a los sulfatos. La probeta de cemento CPN sin adición presenta un aumento de volumen importante y una fisuración uniforme. Estado similar se observa en las que se ha reemplazado el $30 \%$ de cemento. En cambio, las que contienen $20 \%$ de ceniza volante presentan un mayor deterioro.

\section{CONCLUSIONES}

Del presente estudio se pueden extraer las siguientes conclusiones finales:

1) El método propuesto por Koch \&

Steinegger es apropiado para determinar la resistencia a los sulfatos de cementos portland que contienen ceniza volante. Parece conveniente prolongar los ensayos hasta un año.
In figure 10 it is shown prisms final state at $21+340$ days of sulfate exposition. CPN cement specimen without addition presents an important volum increase and an uniform fissuration, similar state is observed in those with $30 \%$ cement replacement. But, those with $20 \%$ of fly ash present greater damage.

\section{COCLUSIONS}

Final conclusions resulting from the present study are:

1) Koch-Steinegger method is appropiated to determine sulfate resistance of portland cements with fly ash. It seems to be convenient to extend the tests duration until a year. 
2) La ceniza volante de procedencia argentina (clase F) presenta un buen comportamiento cuando se adiciona al cemento para contrarrestar el ataque de sulfatos a la matriz del mortero.

3) La resistencia química frente a la agresión de sulfatos del ceniento portland normal se ve notablemente mejorada por la adición de ceniza volante. Este increnento no es tan marcado para el cemento portland resistente a los sulfatos.

4) El reemplazo del $30 \%$ de cemento por ceniza volante, en peso, presenta un mejor comportamiento químico que el correspondiente a un reemplazo del $20 \%$ en los casos estudiados. Debe esperarse una menor resistencia mecánica en las primeras edades.
2) Argentinian fly ash (Class F) presents a good behaviour when it is added to the cement to improve sulfate resistance of mortar matrix.

3) Chemical resistance in front of sulfate attack of ordinary portland cement is notably improved by fly ash addition. This increase isn't too evident for portland sulfate resistent cement.

4) Replacement of $30 \%$ cement by fly ash in weight, shows better chemical behaviour than $20 \%$ replacement in studied cases. It must be expected less mechanical strength in first ages.

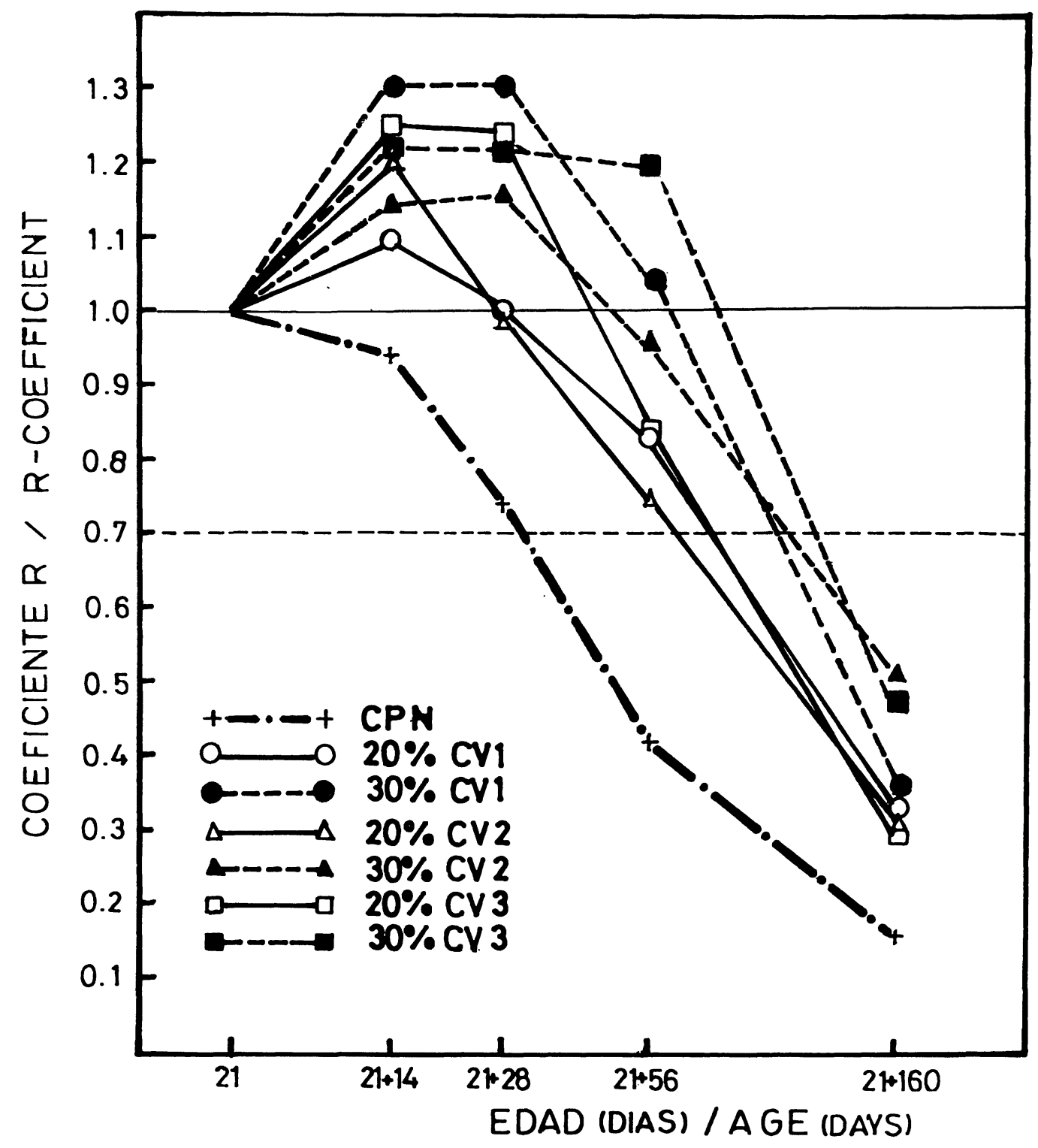

Fig. 8.-Variación del Coeficiente de corrosión R en las mezclas confeccionadas con cemento CPN.

Fig. 8.-R-Corrosion coefficient variation in mortars with made CPN cement. 


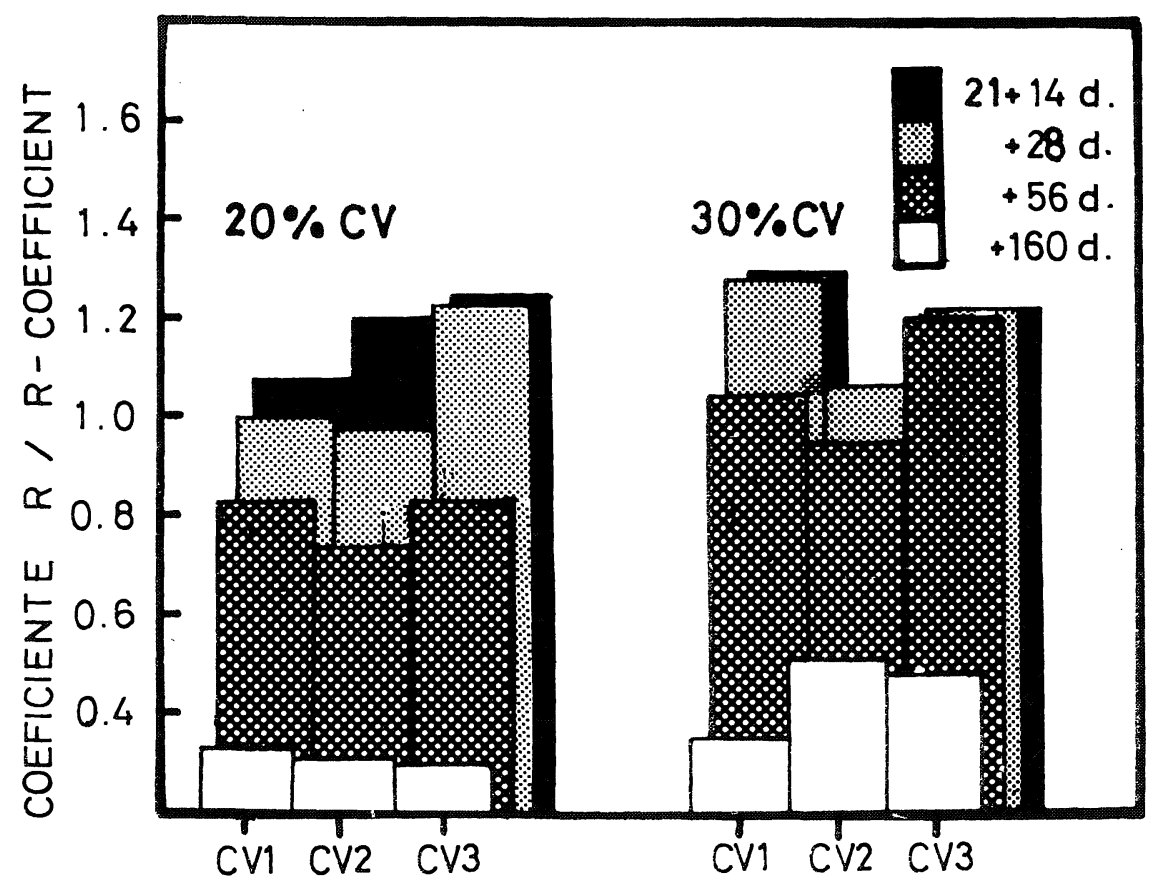

Fig. 9.-Variación del coeficiente de corrosión con la finura de la ceniza volante y tiempo.

Fig. 9.-R-Corrosion coefficient variation with fly ash fineness and age.

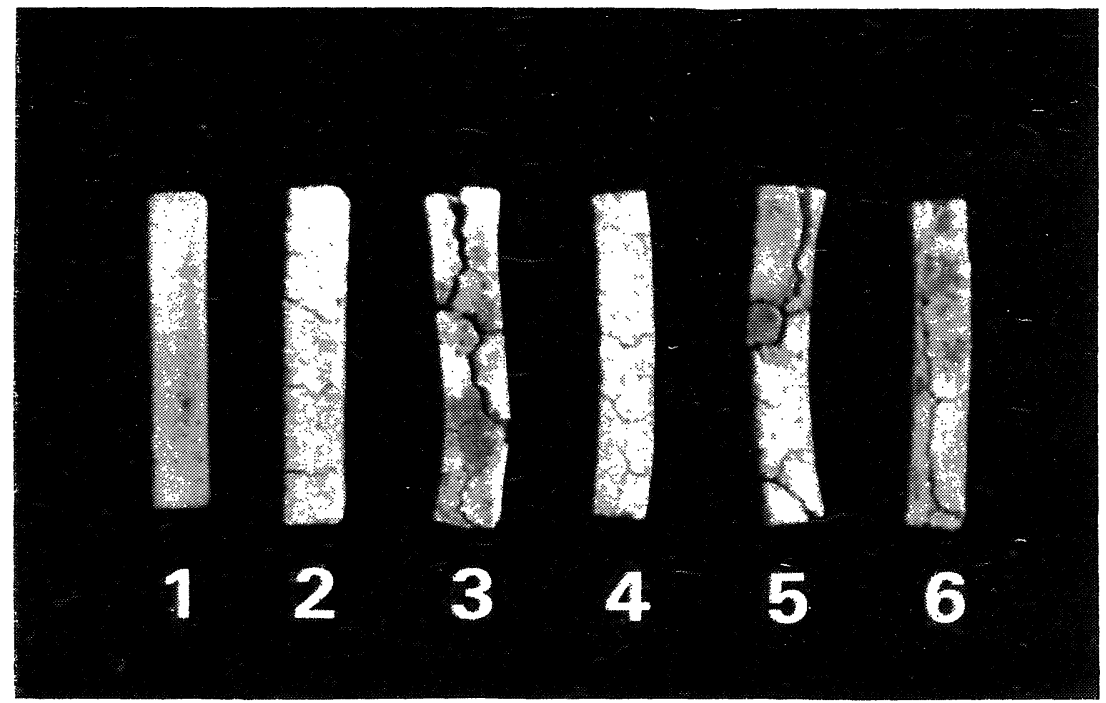

Fig. 10.-Aspecto visual de las probetas confeccionadas con cemento portland normal y ceniza volante al cabo de $21+340$ dias.

Fig. 10.-Visual aspect of prisms made with CPN-cement and fly ash at $21+340$ days.

(1) Control (Control). (2) Cemento (Cement). (3) $20 \%$ CV1. (4) $30 \%$ CV1. (5) $20 \%$ CV3. (6) $30 \%$ CV3.

5) El decaimiento del coeficiente de corrosión de las mezclas que contienen ceniza volante y cemento portland resistente a los sulfatos, es atribuible a la corrosión seienitosa - formación de yeso-debido a la aita concentración de sulfatos en la disolución y la elevada razón agua/ligante especiricada en el método.
5) Corrosion coeficient ( $R$ ) decrease in cements with fly ash and portland sulfate resistent cements, can be due to selenitic corrosion - gypsum formation-due to high sulfate concentration in the solution and to the high water/cement ratio specified in the method. 
6) La finura de la ceniza volante influye marcadamente en la resistencia a la flexión de los prismas en solución de sulfatos durante las primeras edades, finalmente todas alcanzan resistencia similares. Igual observación se ha realizado sobre el Coeficiente de corrosión.

7) El progreso de la resistencia mecánica de las probetas de mortero estacionadas en agua dependen en gran medida de la finura de la adición utilizada, pero también se pone en evidencia la influencia que tiene la composición del cemento a utilizar.

8) Dos aspectos del método de ensayo deberían ser estudiados con detenimiento cuando se evaluan cementos portland compuestos: el tiempo de curado previo a la exposición y la concentración de la solución agresiva.
6) Fly ash fineness influences flexural strength of prisms stored in sulfate solution during first ages, finally all reach similar strengths. Equal behaviour has been found on corrosion coeficient.

7) The development of mechanical strength of mortar specimens cured in water depends mainly on the addition fineness, by it is also evident the influence of cement composition.

8) There should be studied two aspects of the method when there are evaluated blended portland cement: previous curing time and agressive solution concentration.

\title{
5. BIBLIOGRAFIA
}

[1] STARK, D. (1982): “Long time study of concrete durability in sulfate soils”. ACI SP-77, 21-40.

[2] KALOUSEK, G. L. PORTER, L. C. BENTON, E. J. (1972): “Concrete for long time service in sulfate enviroment". Cem. and Conc. Research. V. 2, 79-89.

[3] MEHTA, P. K. (1986): "Effect of fly ash composition on sulfate resistance of cements". ACI Journal. V. 83, 994-1.000.

[4] IRASSAR, E. F. (1987): “Determinación de la resistencia a los sulfatos: Ensayos previos”. Proc. Bva Reunión Tec. A.A.T.H. Tomo I, 41-52.

[5] JASPER, M. J. (1977): "Contribución a l'etude experimentale de la resistance chimique de ciments mesure selon la methode d'immersion de microprismes (MIM) en solution agressive". Rev. Mat. de Const. 704, 1/77, 51-58.

[6] CALLEJA, J. (1980): “Durabilite”. 7 mo Cong. Chim. Cim. Paris 1980. VII-2, 1-49.

\section{publicación del IETcc/CSIC}

\author{
ACUEDUCTOS ROMANOS EN ESPAÑA \\ Carlos Fernández Casado
}

Prof. Dr. Ing. de Caminos, Canales y Puertos

Esta publicación se compone de una serie de articulos, publicados en la Revista "Informes de la Construcción", en los cuales se hace un análisis de los acueductos romanos que existen en España y el balance de las condiciones de conservación en que se encuentra cada uno de ellos, incluyendo referencias históricas y literarias. Se ha ilustrado con la reproducción de la valiosa documentación gráfica que posee el prestigioso autor.

Un volumen encuadernado en couché, a dos colores, de $21 \times 27$ centimetros, compuesto de 238 páginas, numerosos grabados, dibujos, fotos en blanco y negro y figuras de linea.

Precio: España, 900 ptas., 13 \$ USA.

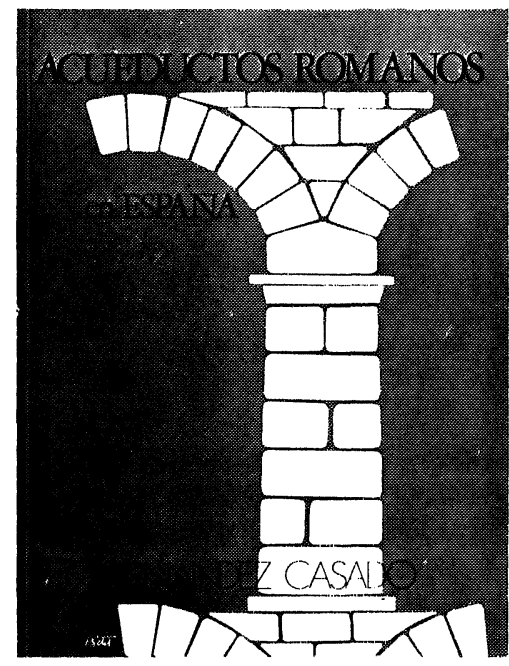

